\title{
TÌNH TRẠNG SUY DINH DƯỠNG CỦA BỆNH NHÂN SUY THẬN MẠN TÍNH CÓ LỌC MÁU CHU KỲ TẠI BỆNH VIỆN TRUNG ƯƠNG THÁI NGUYÊN
}

\author{
Ngô Thị Hà*, Trương Thị Thùy Dương*, Trần Tuấn Tú*

\section{I. ĐĂT VẤN ĐỀ}

TÓM TẮT

Đắt vấn đề: Bệnh nhân suy thận mạn và đặc biệt là nhóm bệnh nhân có lọc máu chu kỳ, liên quan chă̆t chẽ tới tình trạng suy dinh dưỡng của bệnh nhân do cơ thể giảm protein và giảm năng lượng dự trữ. Mục tiêu: Đánh giá tình trạng suy dinh dưỡng của bệnh nhân suy thân man tính có loc máu chu kì tai bểnh viện Trung Ửơng Thái nguyên năm 2020.Đối tượng và phương pháp nghiên cứu: Nghiên cứu được tiến hành theo phương pháp mô tả, thiết kế cắt ngang trên toàn bộ bệnh nhân suy thận mạn tính có lọc máu chu kỳ tại khoa Nội Thận tiết niệu và lọc máu bênh viện Trung Ương Thái Nguyên. Kểt quả nghiên cứu: Tỷ lệ bệnh nhân bị thiếu năng lượng trường diễn (BMI $<18,5)$ chiếm tỷ lê khá cao $(27,8 \%)$. Thời gian điêu trị của người bệnh càng dài thì tỷ lệ thiếu năng lượng trường diến càng cao (đánh giá bằng chỉ số $\mathrm{BMI}$ ) với $\mathrm{p}$ $<0,05$. Đánh giá tình trang dinh dưỡng theo phương pháp SGA có tới $58,3 \%$ bệnh nhân bị SDD nhẹ, 2,2\% bênh nhân bi SDD năng.

Tư khoá: Suy dinh dương, suy thận mạn tính, loc máu chu kỳ, bệnh viện Trung Ương Thái Nguyên.

\section{SUMMARY}

NUTRITION STATUS OF CHRONIC RENAL FAILURE PATIENT WITH DIALYSIS CYCLE AT THAI NGUYEN CENTRAL HOSPITAL

Background: Patients with chronic renal failure and especially those with cyclic dialysis, are closely related to the patient's malnutrition status due to reduced protein and reduced energy reserves. Objective: To assess malnutrition status of patients with chronic renal failure with cyclic dialysis at Thai Nguyen Central Hospital in the year 2020. Research subjects and methods: The study was conducted according to the descriptive method, cross-sectional design on all chronic kidney failure patients with cyclic dialysis at the Department of Nephrology, Urology and Dialysis at Central Hospital. Thai Nguyen. Research results: Percentage of patients with chronic energy deficiency (BMI <18.5) accounted for quite a high rate $(27.8 \%)$. The longer the patient's treatment time, the higher the rate of chronic energy deficiency (assessed by BMI) with $p<0.05$. Assessment of nutritional status according to SGA method had up to $58.3 \%$ of patients with mild malnutrition, $2.2 \%$ of patients with severe malnutrition.

Keywords: Malnutrition, chronic kidney failure, cyclic dialysis, Thai Nguyen Central Hospital.

*Trường Đai hoc Y Dược - Đai hoc Thái Nguyên

Chịu trách nhiệm chính: Ngô Thị Hà

Email: ha97ddig@gmail.com

Ngày nhận bài: 24.2.2021

Ngày phản biên khoa hoc: 30.3.2021

Ngày duyệt bài: 12.3.2021
Bệnh thận mạn tính (BTMT) và bênh thận giai đoạn cuối là vấn đề sức khỏe có tính toàn câu. Bệnh có xu hướng ngày càng tăng nhanh và đòi hỏi chi phí điều trị rất lớn. Suy thân mạn, đặc biêt là giai đoạn phải điều trị thay thế, thực sự là một gánh nặng bệnh tật của xã hội [1].

Theo nghiên cứu của Ahmed. S tại Anh (2011) thì tỷ lệ SDD được phát hiện ở 44,0\% bệnh nhân bị suy thận mạn trước khi phải điều trị thay thế thận [2]. Gần đây của tác giả Nguyễn Thị Thúy Hồng (2019) ở bệnh viện Đa khoa tỉnh Phú Thọ cho thấy tỷ lệ bệnh nhân bị thiếu năng lượng trường diển (BMI $<18,5$ ) chiếm tỷ lệ khá cao (30,2\%). Đánh giá tình trang dinh dưỡng theo phương pháp SGA có tới $62,5 \%$ bệnh nhân bị SDD nhẹ, 5,3\% bệnh nhân bị SDD nắng [3]. Vậy tình trạng suy dinh dưỡng của bệnh nhân suy thận mạn tính có lọc máu chu kỳ ở bệnh viện Đa khoa Trung Ương Thái Nguyên ra sao? Vì vâyy chúng tôi tiến hành đề tài: "Tinh trạng suy dinh dưỡng của bênh nhân suy thận man tính có loc máu chu kỳ tại bệnh viện Trung Ương Thái Nguyên"với mục tiêu:

Đánh giá tinh trạng suy dinh dương của bênh nhân suy thận mạn tính có lọc máu chu kỳ tại bệnh viện Trung Ương Thái nguyên năm 2020.

\section{II. ĐỐI TƯợNG VÀ PHƯƠNG PHÁP NGHIÊN CỨU}

2.1. Đối tượng nghiên cứu. Bệnh nhân mắc bênh suy thân mạn có lọc máu chu kỳ tại bệnh viên Trung Ương Thái Nguyên.

2.2. Thời gian và địa điểm nghiên cứu

- Thời gian: từ ngày 01 tháng 03 năm 2020 đến ngày 30 tháng 08 năm 2020

- Đia điểm: khoa Nội thận tiết niệu và lọc máu bệnh viện Trung Ương Thái Nguyên.

\subsection{Phương pháp nghiên cứu}

2.3.1. Thiết kế nghiên cứu. Nghiên cứu mô tả, thiết kế cắt ngang.

2.3.2. Cỡ mẫu và phương pháp chọn mẫu

- Cõ̃ mẫu: cõ̃ mẫu toàn bộ bệnh nhân suy thận mạn tính có lọc máu chu kỳ.

- Phương pháp chọn mẫu: chọn mẫu có chủ đích toàn bộ bệnh nhẩn suy thận mạn tính có lọc máu chu kỳ tại khoa nội thận tiết niệu và lọc máu bệnh viện Trung Ương Thái Nguyên tại thời điểm nghiên cứu.

2.4. Chỉ số nghiên cứu 
- Đặc điểm thông tin chung của đối tượng nghiên cứu: Tuổi, giới, nghề nghiệp, thu nhập bình quân hàng tháng, thời gian điều trị và khu vực sinh sống.

- Tỷ lệ thiếu năng lượng trường diễn (BMI < 18,5) của đối tượng nghiên cứu.

- Tỷ lệ suy dinh dưỡng theo phương pháp SGA.

- Mức độ suy dinh dưỡng theo phương pháp SGA: nhe và nặng.

- Tỷ lệ thiếu năng lượng trường diễn bằng chỉ số BMI theo nhóm tuổi, thời gian điều trị, theo khu vực sinh sống (nông thôn và thành thị).

2.5. Tiêu chuẩn đánh giá các chỉ số nghiên cứu

- Tuổi bệnh nhân: Hiện nay, người ta tính tuổi khi đánh giá tình trạng dinh dương theo cách quy tuổi về tháng hay năm gần nhất [8].

- Đánh giá tình trạng dinh dưỡng dựa vào chỉ số BMI và phân loại theo Tổ chức $Y$ tế thế giới (WHO) năm 2006 [8]:

BMI = cân nặng/(chiều cao $)^{2}$

Bảng 2.1. Phân loại tình trạng dinh dướng dựa vào chí số BMI của WHO 2006 [8]

\begin{tabular}{|c|c|}
\hline Phân loại & $\mathbf{B M I}\left(\mathbf{k g} / \mathbf{m}^{\mathbf{2}} \mathbf{)}\right.$ \\
\hline Thiếu cân & $<18,5$ \\
\hline Bình thường & $18,5-24,9$ \\
\hline Thừa cân & $\geq 25$ \\
\hline Tiên béo phì & $25-29,9$ \\
\hline Béo phì độ 1 & $30-34,9$ \\
\hline Béo phì độ 2 & $35-39,9$ \\
\hline Béo phì độ 3 & $\geq 40$ \\
\hline
\end{tabular}

- Đánh giá tình trạng dinh dưỡng bằng phương pháp SGA:

\section{Thang điểm:}

1 - 14 điểm: Tình trang dinh dưỡng tốt

15 - 35 điểm: Suy dinh dương nhẹ

36 - 49 điểm: Suy dinh dưỡng nặng

Bảng 2.2. Đánh giá tình trạng dinh dưỡng bằng phương pháp SGA [9]

\begin{tabular}{|c|c|c|}
\hline \multicolumn{2}{|c|}{ Các tiêu chí đánh giá } & $\begin{array}{l}\text { Thang } \\
\text { điểm }\end{array}$ \\
\hline \multirow{3}{*}{$\begin{array}{l}\text { Giảm cân } \\
\text { trong vòng } \\
6 \text { tháng }\end{array}$} & $\begin{array}{c}\text { Không giảm, giảm ít: } \\
0,5-1 \mathrm{~kg}\end{array}$ & $1-2$ \\
\hline & $\begin{array}{c}\text { Giảm }>1 \mathrm{~kg} \text { nhưng }<5 \% \\
\text { trọng lượng cơ thể }\end{array}$ & 3- 5 \\
\hline & $\begin{array}{c}\text { Giảm }>5 \% \text { trọng lượng } \\
\text { cơ thể }\end{array}$ & $6-7$ \\
\hline \multirow{3}{*}{$\begin{array}{l}\text { Thay đổi } \\
\text { chế độ ăn }\end{array}$} & Không đổi & $1-2$ \\
\hline & Giảm thức ăn khô & 3-5 \\
\hline & $\begin{array}{c}\text { Àn ngày càng giảm các } \\
\text { loại thức ăn }\end{array}$ & $6-7$ \\
\hline \multirow{3}{*}{$\begin{array}{l}\text { Biểu hiện } \\
\text { của các triệu } \\
\text { chứng: rối }\end{array}$} & İt, không có & $1-2$ \\
\hline & Thinh thoảng & $3-5$ \\
\hline & Thường xuyên & $6-7$ \\
\hline
\end{tabular}

\begin{tabular}{|c|c|c|}
\hline $\begin{array}{l}\text { loạn tiêu } \\
\text { hoá, sốt... }\end{array}$ & & \\
\hline \multirow{3}{*}{$\begin{array}{l}\text { Tình trang } \\
\text { sức khỏe, } \\
\text { thể lực }\end{array}$} & Thể lực ổn định & $1-2$ \\
\hline & Sức khỏe có suy giảm nhe & $3-5$ \\
\hline & $\begin{array}{l}\text { Sức khỏe suy giảm trầm } \\
\text { trọng, thể lực xấu }\end{array}$ & 6-7 \\
\hline \multirow{3}{*}{$\begin{array}{l}\text { Sứ suy giảm } \\
\text { lớp mõ dưới } \\
\text { da }\end{array}$} & Giảm ít hoặc không giảm & $1-2$ \\
\hline & $\begin{array}{l}\text { Giảm nhe trên toàn bộ } \\
\text { diên tích dưới da }\end{array}$ & 3-5 \\
\hline & $\begin{array}{c}\text { Giảm nặng trên vài phân } \\
\text { hoặc hầu hết }\end{array}$ & 6-7 \\
\hline \multirow{3}{*}{$\begin{array}{l}\text { Sự hao mòn } \\
\text { cơ }\end{array}$} & Giảm ít hoặc không giảm & $1-2$ \\
\hline & $\begin{array}{l}\text { Giảm nhe trên toàn bộ } \\
\text { diện tích dưới da }\end{array}$ & $3-5$ \\
\hline & $\begin{array}{c}\text { Giảm nặng trên vài phân } \\
\text { hoặc hầu hết }\end{array}$ & $6-7$ \\
\hline \multirow{3}{*}{$\begin{array}{l}\text { Hội chứng } \\
\text { phù }\end{array}$} & $\begin{array}{l}\text { Không phù hoăc phù ít } \\
\text { (khó thấy ) }\end{array}$ & $1-2$ \\
\hline & Phù trung bình & 3-5 \\
\hline & Phù nhiều & $6-7$ \\
\hline
\end{tabular}

\subsection{Kỹ thuật tiến hành}

*Cân nặng: Kỹ thuật cân: Sử dụng cân Tanita với độ chính xác đến $0,1 \mathrm{~kg}$. Đặt cân ở vị trí bằng phẳng, chắc chắn, thuận tiện cho bệnh nhân bước lên bước xuống khi cân. Chỉnh cân về vị trí " 0 ".

Khi cân bệnh nhân mặc quần áo mỏng (trang phục cho bệnh nhân trong bệnh viện), bỏ giày dép. Mỗi bệnh nhân được cân tại 2 thời điểm:

- Trước lọc: ngay trước lọc máu, chỉ số này được sử dụng để đánh giá tình trạng tăng cân giữa 2 kỳ lọc, đồng thời để xác định lượng nước thực được rút trong buổi lọc đó (trừ đi cân nặng sau loc).

- Sau lọc: ngay sau khi cuộc lọc, tương đương trọng lượng khồ tương đối của bệnh nhân.

Mỗi bệnh nhân được cân sau khi cuộc lọc kết thúc 10-20 phút, cân trong 3 buổi lọc liên tiếp, kết quả trung bình của 3 lần lọc đo được coi là trong lượng khô tương đối và đưa vào tính toán thống kề. Bệnh nhân đứng vào giữa bàn cân ở tư thế đứng thẳng và yên lặng, không chạm vào bất cứ vật gì xung quanh. Khi cân ổn định, đọc và ghi lại kết quả với đơn vị là kg và một số lẻ.

- Cân nặng là trọng lượng khô tương đối được tính là kết quả trung bình của 3 lần cân trong 3 buổi lọc liên tiếp.

\section{*Chiều cao:}

- Kỹ thuật đo: Sử dụng thước gỗ của Unicef. Thước được đóng trên một mặt phẳng (tường buồng bệnh), tại điểm khi kéo chạm đất, thước sẽ ở $0 \mathrm{~cm}$.

- Bệnh nhân bỏ giày dép, mũ và đứng quay lưng vào thước đo, giữa trục của thước, hai tay 
buông thõng tự nhiên.

- Kiểm tra các điểm chạm của cơ thể vào mặt phẳng thẳng đứng đóng thước: chẩm, vai, mông, bắp chân và gót chân. Đọc và ghi lại kết quả với đơn vị là $\mathrm{cm}$ và một số lẻ [4].

2.7. Xử lý số liệu. Số liệu được làm sạch, mã hóa, nhập trên phần mềm Epi data 3.1 và xử lý trên phần mềm SPSS 20.0 với các test thống kê thích hợp.

\section{KẾT QUẢ NGHIÊN CỨU}

Bảng 3.1. Phân bố đối tượng nghiên cứu theo nhóm tuối

\begin{tabular}{|c|c|c|}
\hline Nhóm tuối & SL & \% \\
\hline$<40$ & 40 & 18,0 \\
\hline $40-60$ & 87 & 39,0 \\
\hline$>60$ & 96 & 43,0 \\
\hline Tống số & 223 & 100 \\
\hline
\end{tabular}

Nhận xét: Trong tống số 233 bệnh nhân, bệnh nhân ở nhóm tuổi 60 chiếm tỷ lệ cao nhất $(43,0 \%)$, tiếp đến là nhóm tuổi từ $40-60$ chiếm $39 \%$ và nhóm tuổi < 40 chiếm tỳ lệ thấp nhất
$18,0 \%)$.

Bảng 3.2. Phân bố đôi tượng nghiên cứu theo gióí

\begin{tabular}{|c|c|c|}
\hline Giới tính & SL & \% \\
\hline Nam & 114 & 51,1 \\
\hline Nữ & 109 & 48,9 \\
\hline Tống số & 223 & 100 \\
\hline
\end{tabular}

Nhận xét: Trong tổng số 223 đối tượng nghiên cứu, số bệnh nhân nam chiếm $51,1 \%$ cao hơn bệnh nhân nữ (chiếm 48,9\%).

Bảng 3.3. Thu nhập trung bình hàng tháng của đối tượng nghiên cứu

\begin{tabular}{|c|c|c|}
\hline $\begin{array}{c}\text { Thu nhập bình } \\
\text { quân/tháng }\end{array}$ & SL & \% \\
\hline$<3$ triệu đồng & 169 & 75,8 \\
\hline$\geq 3$ triệu đồng & 54 & 24,2 \\
\hline Tống số & $\mathbf{2 2 3}$ & $\mathbf{1 0 0}$ \\
\hline
\end{tabular}

Nhận xét: Thu nhập của người bệnh trung bình trong một tháng với mức dưới 3 triệu chiếm tỷ lệ cao hơn rõ rệt so với người có thu nhập từ 3 triệu trở lên (chiếm 75,8\%).

Bảng 3.4. Phân bố bệnh nhân theo thời gian điều trị và khu vực sinh sống

\begin{tabular}{|c|c|c|c|c|c|c|c|c|}
\hline \multirow{2}{*}{$\begin{array}{l}\text { Thời gian điêu trị } \\
\text { Khu vực sinh sống }\end{array}$} & \multicolumn{2}{|c|}{ < 4 năm } & \multicolumn{2}{|c|}{4 - 8 năm } & \multicolumn{2}{|c|}{$>8$ năm } & \multicolumn{2}{|c|}{ Tống } \\
\hline & SL & $\%$ & SL & $\%$ & SL & $\%$ & SL & $\%$ \\
\hline Thành thị & 44 & 17,9 & 29 & 13,0 & 17 & 7,6 & 90 & 40,3 \\
\hline Nông thôn & 69 & 30,9 & 38 & 17,1 & 26 & 11,7 & 133 & 59,7 \\
\hline Tống số & 113 & 50,6 & 67 & 30,1 & 43 & 19,36 & 223 & 100 \\
\hline
\end{tabular}

Nhân xét: Thời gian điều trị của người bênh sống ở khu vực nông thôn chiếm tỷ lệ cao hơn người bệnh sống ở khu vực thành thị. Tuy nhiên sự khác biệt về thời gian điều trị của người bệnh sống ở thành thị và nông thôn không có ý nghĩa thống kê với p > 0,05.

Bảng 3.5. Tình trạng dinh dướng của bệnh nhân theo chí số BMI

\begin{tabular}{|c|c|c|c|c|c|c|}
\hline \multirow{2}{*}{ BMI Giới } & \multicolumn{2}{|c|}{ Nam } & \multicolumn{2}{c|}{ Nữ } & \multicolumn{2}{c|}{ Tổng số } \\
\cline { 2 - 7 } & SL & \% & SL & \% & SL & \% \\
\hline BMI $<18,5$ & 28 & 12,6 & 34 & 15,2 & 62 & 27,8 \\
\hline BMI 18,5-24,9 & 78 & 35,0 & 68 & 30,5 & 146 & 65,5 \\
\hline BMI $\geq 25$ & 8 & 3,6 & 7 & 3,1 & 15 & 6,7 \\
\hline Tống số & 114 & 51,2 & 109 & 48,8 & 223 & 100 \\
\hline
\end{tabular}

Nhận xét: Theo phân loại của WHO năm 2007: bệnh nhân bị thiếu năng lượng trường diễn chiếm tỷ lệ khá cao (27,8\%); 65,5\% bệnh nhân có BMI trong giới hạn bình thường; số bệnh nhân bị thừa cân, béo phì chiếm tỷ lệ thấp $(6,7 \%)$.

Bảng 3.6. Đánh giá tình trạng dinh dưỡng của đôi tượng nghiên cứu theo phương pháp SGA (đánh giá tổng thể đôî tượng)

\begin{tabular}{|c|c|c|}
\hline Điểm số theo phương pháp SGA & SL & \% \\
\hline $1-14$ (tinh trạng dinh dưỡng tốt) & 88 & 39,5 \\
\hline $15-35$ (suy dinh dưỡng nhẹ) & 130 & 58,3 \\
\hline $36-49$ (suy dinh dưỡng nặng) & 5 & 2,2 \\
\hline Tổng số & 223 & 100 \\
\hline
\end{tabular}

Nhận xét: Kết quả ở bảng cho thấy, có tới 58,3\% bệnh nhân bị suy dinh dưỡng nhẹ và 2,2\% bệnh nhân bị suy dinh dưỡng nặng.

Bảng 3.7. Tình trạng thiếu năng lượng trường diễn bằng chỉ số BMI (TNLTD) theo nhóm tuổi của đôî tượng nghiên cứu 


\begin{tabular}{|c|c|c|c|c|c|c|}
\hline \multirow{2}{*}{ Nhóm tuổi } & \multicolumn{2}{|c|}{ Thiếu năng lượng trường diền (BMI < 18,5) } & \multicolumn{2}{c|}{ Tống số } \\
\cline { 2 - 7 } & Có & $\mathbf{\%}$ & Không & $\mathbf{\%}$ & SL & $\mathbf{\%}$ \\
\hline$<40$ & 10 & 25,0 & 30 & 75,0 & 40 & 100,0 \\
\hline $40-60$ & 23 & 26,4 & 64 & 73,6 & 87 & 100,0 \\
\hline$>60$ & 34 & 35,4 & 62 & 64,6 & 96 & 100,0 \\
\hline Tống số & 62 & 27,8 & 161 & 72,2 & 223 & 100,0 \\
\hline \multicolumn{7}{|c|}{$\mathrm{p}>0,05$} \\
\hline
\end{tabular}

Nhận xét: Nhóm người bệnh trên 60 tuổi bị thiếu năng lượng trường diễn (đánh giá bằng chỉ số BMI) chiếm tỷ lệ cao nhất (35,4\%), tiếp đến là nhóm người bệnh từ $40-60(26,4 \%)$, chiếm tỷ lệ thấp nhất (25,0\%) ở nhóm người bệnh dưới 40 tuổi. Tuy nhiên sự khác biệt về tỷ lệ thiếu năng lượng trường diễn theo nhóm tuổi không có ý nghĩa thông kê ( $p \geq 0,05)$. tri

Bảng 3.8. Tình trạng thiếu năng lượng trường diễn bằng chỉ số BMI theo thời gian điều

\begin{tabular}{|c|c|c|c|c|c|c|}
\hline \multirow{2}{*}{$\begin{array}{l}\text { Thời glian } \\
\text { điêuu trị (năm) }\end{array}$} & \multicolumn{3}{|c|}{$\begin{array}{c}\text { Thiếu năng lượng trường diền } \\
\text { (BMI < 18,5) }\end{array}$} & \multicolumn{2}{c|}{ Tổng số } \\
\cline { 2 - 7 } & Có & $\mathbf{\%}$ & Không & \% & SL & $\%$ \\
\hline$<4$ & 9 & 20,9 & 34 & 58,2 & 43 & 100,0 \\
\hline $4-8$ & 18 & 26,9 & 49 & 73,1 & 67 & 100,0 \\
\hline$>8$ & 35 & 32,1 & 74 & 67,9 & 109 & 100,0 \\
\hline Tống số & 62 & 27,8 & 161 & 72,2 & 223 & 100,0 \\
\hline \multicolumn{7}{|c|}{$\mathrm{p}<0,05$} \\
\hline
\end{tabular}

Nhận xét: Số người bệnh bị thiếu năng lượng trường diễn (đánh giá bằng chỉ số BMI) điều trị trên 8 năm chiếm tỷ lệ cao nhất $(32,1 \%)$, tiếp đến là người bệnh điều trị từ 4 - 8 năm $(26,9 \%)$, chiếm tỷ lệ thấp nhất là nhóm người bệnh dưới 4 năm điều trị (20,9\%). Sự khác biệt về tình trạng thiếu năng lượng trường diễn theo thời gian điêu trị của người bệnh có ý nghĩa thông kê với $p<0,05$.

\section{BÀN LUẬN}

4.1. Đặc điểm chung của đối tượng nghiên cứu. Kết quả nghiên cứu của chúng tôi cho thấy, trong tổng số 233 bệnh nhân, bệnh nhân ở nhóm tuổi 60 chiếm tỷ lệ cao nhất $(43,0 \%)$, tiếp đến là nhóm tuổi từ 40 - 60 chiếm $39,0 \%$ và nhóm tuổi <40 chiếm tỷ lệ thấp nhất $18,0 \%)$. Tỷ lệ bệnh nhân nam (51,1\%) cao hơn bệnh nhân nữ $(48,9 \%)$. Kết quả này của tôi tương đương với kết quả nghiên cứu của tác giả Nguyền Thị Thúy Hồng (2019) trên bệnh nhân suy thận mạn tính có lọc máu chu kỳ ở bệnh viện Đa khoa Phú Thọ [3].

Người bệnh có thu nhập bình quân hàng tháng chủ yếu là dưới 3 triệu đồng chiếm tỷ lệ khá cao $(75,8 \%)$, số người bệnh có thu nhập trên 3 triệu đồng chỉ có $24,2 \%$. Trong khi chi phí cho các cuộc lọc hàng tháng nếu người bệnh không bảo hiểm y tế cũng phải mất khoảng từ 8 đến 10 triệu đồng Việt Nam. Trong nghiên cứu của tôi phần lớn là bệnh nhân trong hộ nghèo nên được chi trả toàn bộ chi phí về lọc máu, siêu lọc và̀ thuốc tăng hồng cầu cũng như chi phí về xét nghiệm. Tuy nhiên bệnh nhân phải chi phí cho việc đi lại, ăn ở, sinh hoạt hàng ngày nhất là những người bệnh ở xa đến lọc máu ngoại trú tại bệnh viện và đặc biệt phải sử dụng một số thuốc đắt tiền hỗ trợ tăng sinh hồng cầu trong danh mục bảo hiểm y tế không chi trả. Đây cũng chính là nguyên nhân góp phần làm cho tỷ lệ suy dinh dưỡng của bệnh nhân STMT LMCK chiếm tỷ lệ cao.

Kết quả ở bảng 3.4 cho thấy tỷ lệ bệnh nhân ở khu vực nông thôn chiếm tỷ lệ cao hơn $(59,7 \%)$, tỷ lệ bệnh nhân ở khu vực thành thị thấp hơn $(40,3 \%)$. Kết quả này của tôi tương đương với kết quả nghiên cứu của tác giả Nguyền Thị Thúy Hồng (2019) [3]. Tuy nhiên sự khác biệt về thời gian điều trị của người bệnh sống ở thành thị và nông thôn không có ý nghĩa thống kê với $p>0,05$.

4.2. Đánh giá tình trạng suy dinh dưỡng của bệnh nhân suy thẩn mạn tính có lọc máu chu kỳ tại bệnh viện Trung Ương Thái Nguyên. Kết quả nghiên cứu ở bảng 3.3 cho thấy, bệnh nhân bị thiếu năng lượng trường diễn chiếm tỷ lệ khá cao $(27,8 \%)$. Kết quả nghiên cứu của tôi thấp hơn kết quả nghiên cứu của tác giả Trần Văn Nhường tại bệnh viện Hữu Nghị Việt Đức năm 2013 (37,2\%) [7], Trần Thị Yến (2018) taai bệnh viện tỉnh Thái Bình (36,5\%) [5] và Nguyễn Thị Thúy Hồng năm 2019 (30,2\%) [3]. Có thể giải thích rằng các nghiên cứu được tiến hành ở các địa điểm và thời điểm khác nhau. BMI thấp là hậu quả của việc giảm khối mõ và khối cơ trên bệnh nhân. 
Khi sử dụng phương pháp SGA để đánh giá tình trạng dinh dưỡng, kết quả nghiên cứu của chúng tôi cho thấy có tới $58,3 \%$ bệnh nhân bị suy dinh dưỡng nhẹ và $2,2 \%$ bệnh nhân bị suy dinh dưỡng nặng. Tỷ lệ suy dinh dưỡng nhẹ của chúng tôi thấp hơn kết quả nghiên cứu của tác giả Trần Văn Nhượng (2013) cho thấy có $70,7 \%$ bệnh nhân bị SDD nhẹ, 10\% bệnh nhân bị SDD nặng, chỉ có $19,3 \%$ bệnh nhân có tình trạng dinh dưỡng tốt [6] và tác giả Nguyễn Thị Thúy Hồng (2019) trong số 155 bệnh nhân thì có $62,5 \%$ bệnh nhân bị SDD nhẹ, 5,3\% bệnh nhân bị SDD nắng [3]. Phương pháp SGA đưa ra những tiêu chí đánh giá toàn diện tình trạng dinh dưỡng của người bệnh giúp cho các nhà lâm sàng đưa ra những phương pháp can thiệp dinh dưỡng đặc hiệu góp phần quan trọng nhằm cải thiện chất lượng điều trị cho người bệnh.

Nhóm người bệnh trên 60 tuổi bị TNLTD theo chỉ số BMI chiếm tỷ lệ cao nhất ( $35,4 \%$ ), chiếm tỷ lệ thấp nhất $(25,0 \%)$ ở nhóm người bệnh dưới 40 tuổi (bảng 3.7). Tuy nhiên sự khác biệt về tỷ lệ thiếu năng lượng trường diễn theo nhóm tuổi không có ý nghĩa thông kê $(p>0,05)$. Kết quả này của chúng tôi tương đương với kết quả nghiên cứu của tác giả Nguyễn Thị Thúy Hồng (2019): Nhóm người bệnh trên 60 tuổi bị thiếu năng lượng trường diễn (đánh giá bằng chỉ số BMI) chiếm tỷ lệ cao nhất $(36,8 \%)$, tiếp đến là nhóm tuổi 40 - $60(28,2 \%)$, chiếm tỷ lệ thấp nhất $(27,9 \%)$ với nhóm người bệnh dưới 40 tuổi. Tuy nhiên sự khác biệt về tỷ lệ thiếu năng lượng trường diễn theo nhóm tuổi không có ý nghĩa thông kê $(p>0,05)[3]$.

Kết quả nghiên cứu của chúng tôi ở bảng 3.8 cho thây: Số người bệnh bị TNLTD (đánh giá bằng chỉ số $\mathrm{BMI}$ ) điều trị trên 8 năm chiếm tỷ lệ cao nhất $(32,1 \%)$, chiếm tỷ lệ thấp nhất là nhóm người bệnh dưới 4 năm điều trị $(20,9)$ với $p$ < 0,05 . Kết quả này của chúng tôi phù hợp với kết quả nghiên cứu của tác giả Trần Văn Nhượng (2013): thời gian điều trị trên 8 năm 55,2\% bệnh nhân bị SDD, từ 4 đến 8 năm điêu trị $37,5 \%$, còn dưới 4 năm là $29,2 \%(p<0,05)$ [7] và tác giả Nguyễn Thị Thúy Hồng (2019): số người bệnh bị thiếu năng lượng trường diễn (đánh giá bằng chỉ số $\mathrm{BMI}$ ) điều trị trên 8 năm chiếm tỷ lệ cao nhất $(48,4 \%)$, tiếp đến là người bệnh điêu trị từ 4 - 8 năm $(35,1 \%)$, chiếm tỷ lệ thấp nhất $(17,2 \%)$ là nhóm người bệnh dưới 4 năm điều trị $(p<0,05)$. Nhiều nghiên cứu trên thế giới cho thấy thời gian điều trị càng lâu thì tình trạng dinh dưỡng càng giảm [6], [8].

\section{KẾT LUẬN}

- Tỷ lệ bệnh nhân bị thiếu năng lượng trường diễn (BMI < 18,5) chiếm tỷ lệ khá cao $(27,8 \%)$.

- Thời gian điều trị của người bệnh càng dài thì tỷ lệ thiếu năng lượng trường diễn càng cao (đánh giá bằng chỉ số $\mathrm{BMI}$ ) với $\mathrm{p}<0,05$.

- Đánh giá tình trạng dinh dưỡng theo phương pháp SGA có tới 58,3\% bệnh nhân bị SDD nhẹ, 2,2\% bệnh nhân bị SDD nặng.

\section{KHUYẾN NGH!}

- Cần tăng cường các biện pháp can thiệp nhằm nâng cao tình trạng thiếu năng lượng trường cho người bệnh.

- Xây dựng chể độ ăn phù hợp với từng giai đoạn bệnh lý và khuyến khích bệnh nhân tuân thủ chế độ ăn nhằm cải thiện tình trạng suy dinh dưỡng.

\section{TÀI LIẸU THAM KHẢO}

1. Aghakhani N., S. Samadzadeh, T. M. Mafi, et al (2012), "The impact of education on nutrition on the quality of life in patients on hemodialysis: a comparative study from teaching hospitals", Saudi J Kidney Dis Transpl, 23(1), pp. $26-30$.

2. Ahmed.S, A.Molhem, et al (2011), "Nutritional assessmet of patients on hemodialysis in a large dialysis center", Saudi J Kidney Dis Transpl, pp. $675-681$.

3. Nguyến Thị Thúy Hồng (2019), "Tình trang dinh dưỡng của bệnh nhân suy thận mạn tính có lọc máu chu kì tại bệnh viện đa khoa Phú Thọ", Tạp chí Y học thực hành, tập 1181, tr. 115 - 117.

4. Trường Đại Học Y Hà Nội (2006), Hướng dẫn thực hanh dinh dưỡng ở cộng đồng, NXB Y học, tr. $15-38$.

5. Trân Thị Yến (2018), "Đặc điểm khẩu phần và một số rối loạn dinh dưỡng ở bệnh nhân suy thận lọc máu chu kì tại hai bệnh viện tỉnh Thái Bình năm 2017", Luân văn thạc sĩ dinh dưỡng, Trường Đại học Y Dược Thái Bình, tr. 38 - 53.

6. Kaysen G, Dubin J, Muller H, Rosales L, Levin N (2000), The acute- phase response varies with time and predicts serum albumin levels in hemodialysis patients, The HEMO Study Group, Kidney Int, 58, pp. 346 - 352.

7. Trân Văn Nhường (2013), Tình trang dinh dưỡng và một số yếu tố liên quan của bệnh nhân suy thận mañ tính có lọc máu chu kỳ tai bệnh viên hữu nghi Việt Đức năm 2012, Luận vằn thạc sĩ y học, Trường Đại học Y tế công cộng, tr. 58 - 76.

8. WHO (2011), Global status report on noncommunicable diseases 2010, WHO press, 20Avenue Appia, 1211 Geneva 27, Switzerland, pp. 152 - 156

9. WHO expert consultation (2004), "Appropriate body-mass index for Asian populations and its implications for policy and intervention strategies", The Lancet, 363, pp. 157 - 163. 